\title{
Reiki therapy in the Unified Health System: meanings and experiences in integral health care
}

\author{
Terapia Reiki no Sistema Único de Saúde: sentidos e experiências na assistência integral à saúde \\ Terapia Reiki en el Sistema Único de Salud: sentidos y experiencias en la asistencia integral de salud
}

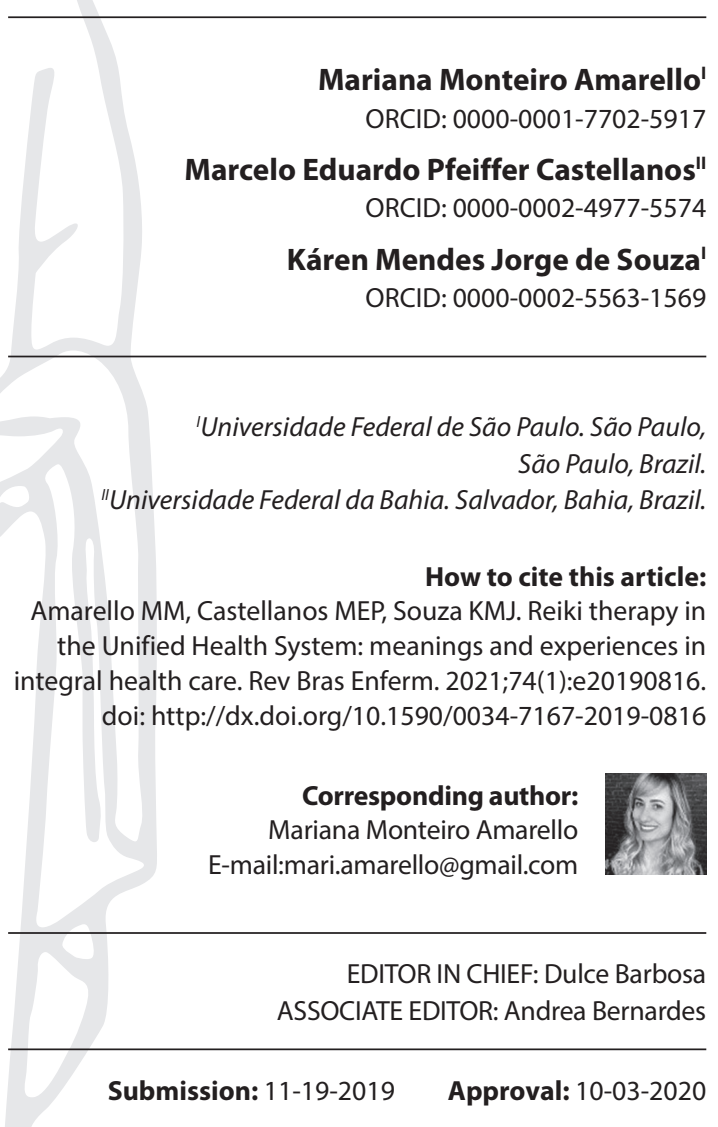

\begin{abstract}
Objectives: to understand the meanings of Reiki therapy in the Unified Health System, based on the experiences of users and therapists. Methods: thematic oral history study, conducted with 12 users and 11 Reiki therapists, in three public health services, in the city of São Paulo, SP, in 2018. The interviews were transcribed and categorized, through thematic content analysis, with the help of the Atlas.ti software. Results: for the interviewees, Reiki activates a universal energy, offering benefits to the body, mind, and spirit. The engagement of therapists in such practice was motivated by the desire to carry out voluntary work. Users claim to seek this therapy to overcome a state of suffering and use natural practices. Final Considerations: the meanings and experiences with Reiki therapy are many, but they converge in the understanding of this practice as a producer of health, well-being, and quality of life, through care centered on the integral human being.

Descriptors: Therapeutic Touch; Complementary Therapies; Unified Health System; Comprehensive Integral Healthcare; Qualitative Research.
\end{abstract}

\section{RESUMO}

Objetivos: compreender os significados da terapia Reiki, no Sistema Único de Saúde, com base nas experiências de usuários e terapeutas. Métodos: estudo de história oral temática, realizado com 12 usuários e 11 terapeutas de Reiki, em três serviços públicos de saúde, no município de São PauloSP, em 2018. As entrevistas foram transcritas e categorizadas, mediante análise de conteúdo temática, com auxílio do Atlas.ti. Resultados: para os entrevistados, o Reiki aciona uma energia universal, oferecendo benefícios ao corpo, à mente e ao espírito. O engajamento dos terapeutas em tal prática foi motivado pelo desejo de realizar trabalho voluntário. Os usuários afirmam buscar essa terapia para superar um estado de sofrimento e utilizar práticas naturais. Considerações Finais: os significados e as experiências com a terapia Reiki são plurais, mas convergem na compreensão dessa prática como produtora de saúde, bem-estar e qualidade de vida, por meio do cuidado centrado no ser humano integral. Descritores: Toque Terapêutico; Terapias Complementares; Sistema Único de Saúde; Assistência Integral à Saúde; Pesquisa Qualitativa.

\section{RESUMEN}

Objetivos: comprender los significados de terapia Reiki, en Sistema Único de Salud, basado en experiencias de usuarios y terapeutas. Métodos: estudio de historia oral temática, realizado con 12 usuarios y 11 terapeutas de Reiki, en tres servicios públicos de salud, en municipio de São Paulo-SP, en 2018. Las entrevistas transcriptas y categorizadas, mediante análisis de contenido temático, con auxilio del Atlas.ti. Resultados: para los entrevistados, el Reiki acciona una energía universal, ofreciendo beneficios al cuerpo, mente y espirito. El compromiso de los terapeutas en tal práctica ha sido motivado por el deseo de realizar trabajo voluntario. Usuarios buscan esa terapia para superar un estado de sufrimiento y utilizar prácticas naturales. Consideraciones Finales: los significados y las experiencias con la terapia Reiki son plurales, pero convergen en la comprensión de esa práctica como productora de salud, bienestar y calidad de vida, por medio del cuidado centrado en el ser humano integral.

Descriptores: Toque Terapéutico; Terapias Complementarias; Sistema Único de Salud; Asistencia Integral de Salud; Investigación Cualitativa. 


\section{INTRODUCTION}

Traditional and complementary medicine (TCM) is an important part of health care, with growing demand in several countries, for health upkeep and treating diseases, especially chronic ones. In this sense, the World Health Organization (WHO), through the WHO Traditional Medicine Strategy 2014-2023 document, encourages the use of traditional, complementary, and integrative medicines in health systems, aiming at the promotion of person-centered care, with safety, quality, and regulation of products, practices and professionals ${ }^{(1)}$.

In Brazil, we can list some advances and challenges in the process of implementing integrative practices in Brazil's Unified Health System, hereinafter referred to as SUS, since the publication of the National Policy for Integrative and Complementary Practices in Health (NPICP) in 2006. Along this path, we can observe an increase in the supply of these practices, especially in Primary Health Care (PHC), with two public policy updates - including 14 practices in 2017 and another 10 in 2018 -, in addition to the growing public approval and increase in the number of scientific studies on the topic. However, as challenges, we emphasize the focus on the dissemination of practices whose conceptions are rooted in allopathic medicine; and the need for greater insertion of integrative and complementary health practices (ICHP) in undergraduate and graduate education, increased budgetary allocation for this purpose in the management of public policy, expansion of professional qualification for these therapies, supply of resources, and specific regulation on practices, based on scientific evidence ${ }^{(2-4)}$.

With the expansion of NPICP practices, Reiki therapy started to be offered to the SUS user population in 2017. Reiki is a therapeutic practice, originating in Japanese culture, that uses the laying on of hands to channel life energy, to stimulate the natural mechanisms of recovery and maintenance of health"(5).

Several scientific studies show health benefits of Reiki therapy, such as: pain relief ${ }^{(6-9)}$, the reduction of stress and anxiety ${ }^{(9-10)}$, better coping with illness and therapeutic processes ${ }^{(11)}$, decreased blood pressure $^{(9)}$, improvement of depressive symptoms ${ }^{(12)}$ and sleep problems ${ }^{(13)}$. However, most of these studies have methodological designs that make little room for the expression of the centrality of the subject in the care process. It is worth noting that "any attempt to exclude subjectivity from the process of illness and cure - due to carelessness or technical imposition - proves to be unsuccessful"(14). Therefore, it is understood that the meanings and effects of Reiki therapy as subjective phenomena, including emotional responses and global judgments of life satisfaction, should also be investigated.

With these considerations, the research problem is delimited based on the following questioning: What are the meanings of Reiki therapy, produced by users and therapists, based on their experiences in SUS services?

The results of this investigation can contribute to the advancement of scientific knowledge in the areas of Nursing and Health, since the boundaries of the present study begin from methodological gaps in scientific investigations on the subject. They can also contribute to care practices in SUS, based on a model of humanized care, which focuses on the integrality of the person, the expanded view of the health-disease process and the promotion of human care, especially self-care. The results, therefore, can benefit users, workers, and management of this system. Finally, it should be noted that knowing the implementation of these new practices is also a significant strategy for monitoring and evaluating the NPICP.

\section{OBJECTIVES}

To understand the meanings of Reiki therapy in SUS, based on the experiences of users and therapists.

\section{METHODS}

\section{Ethical aspects}

The project for this research was approved by the Research Ethics Committee of the Hospital do Servidor Público de São Paulo (HSPM) [Public Servant Hospital of São Paulo], of the Federal University of São Paulo, and the Municipal Health Secretariat of the City of São Paulo. The ethical aspects of research involving human beings were adhered to. Each interviewee participated in the research by signing the Free and Informed Term of Consent (FITC), with confidentiality of information being guaranteed.

\section{Theoretical-methodological framework}

This research is based on the theoretical-methodological framework of oral history, which is a practice of apprehending narratives in order to record people's experiences, as a legitimate expression of the present time, and to promote analyzes of social processes ${ }^{(15)}$ - in this case, the experience of different participants with Reiki therapy in SUS.

Considering that such therapy constitutes a counter-hegemonic movement to the biological based care model, it is understood that oral history fulfills, in this study, one of its functions related to the expression of the sectors that are "without a voice", as a sense of practical and public utility.

Within oral history, the thematic genre was used by starting from a previously established specific subject. In this method, no absolute truth is sought, following a cohesive itinerary, but rather through the recording of a particular version of historical feelings and events narrated by a certain person ${ }^{(15)}$.

\section{Type of study}

Qualitative study based on the methodological framework of thematic oral history. With this study design, the authors adopted the guidelines included in the document Consolidated Criteria for Reporting Qualitative Research (COREQ).

\section{Methodological Procedures}

The oral history consists of the following procedures: preparation of the project, recording, preparation of the written document, analysis and return of the product ${ }^{(15)}$.

In this study, for the construction of the empirical material, the interview, the transcription of the recorded material, the textualization, the transcreation and, finally, the checking of the 
material and obtaining the authorization for use and publication, were carried out sequentially, upon the participant's signature of the Letter of Assignment ${ }^{(15)}$.

\section{Study scenario}

The research was developed in São Paulo, SP, whose Municipal Health Secretariat has been offering traditional and natural medicine treatment options since 2011, in addition to body practices through the Programa de Qualidade de Vida com Medicinas Tradicionais [Quality of Life Program with Traditional Medicines], Homeopathy and Integrative Practices in Health, which is developed in several health units, including five specialized Natural Practice Centers (NPCs), namely: NPC Ermelino Matarazzo, NPC Guaianases, NPC Bosque da Saúde, NPC São Mateus and NPC Cidade Tiradentes.

This study was carried out in two NPCs and in a public hospital, a pioneer in offering comprehensive health care in a humanized way, valuing several integrative and complementary health practices.

\section{Data source}

23 collaborators participated in the research, being 11 therapists and 12 Reiki users. The inclusion criteria were: for therapists - to have experience of at least one year with the practice of Reiki; for users - be over 18 and have received Reiki at least three times. Users were invited to participate in the study, mediated by therapists, following snowball sampling.

\section{Data collection and organization}

Data were collected through audio-recorded interviews from March to June 2018. Questions addressed to therapists and users were designed with the objective of knowing and understanding their experiences and interpretative perspectives towards the theme. With therapists, the interviews explored the meanings and benefits of Reiki, as well as the motivations for working as a therapist in SUS. With the users, they explored the meanings and benefits of this therapy and the motivations and experiences in using it in the health services surveyed.

The pre-interview expressed the first contact between the researcher and the participant. At that moment, the collaborators were informed about the research objective, as well as clarified about their way of participating in the study.

The interviews were conducted by the first author, nurse practitioner, and Reiki therapist, after methodological deepening in the referential of thematic oral history. It should be noted that the participants were unaware of the interviewer's Reiki training. The interviews were carried out in private rooms, to guarantee the interviewees' privacy and reduce noise or interruptions; they did not have a pre-established duration, but an average duration of one hour. The interviewees chose codenames related to nature, for the presentation of the narratives.

At each interview, we used fieldnotes in order to record the researcher's impressions pertaining to the contact with the collaborator, the environment in which the interview took place, and the difficulties encountered during the course of construction of the empirical material.
After the interviews, the textualization stage was the moment to transliterate the collaborator's speech and include the interviewer's speech in a dialogical and textual process, leaving the text clear and in first person. In this phase, strong expressions of the stories were identified to choose the vital tone ${ }^{(15)}$, which represents a guide or synthesis of the narrative. During post-interview, the collaborators were informed about the subsequent steps, which refer to the transformation of the speech from an oral to a written stage.

The transcreation stage allowed the reproduction of the text in its fullness, through a literary language, including the emotions of the collaborators, for the composition of a final text, which was presented, verified, and authorized for publication by the study collaborators.

After methodological procedures of oral history, the narratives produced were inserted in the Atlas.ti software, version 8.2, which offers resources for the identification, interpretation, and correspondence of registration units and units of meaning, which were gathered due to the recurrence and importance of the themes.

\section{Data analysis}

Through the analysis of narratives, the thematic content analysis technique was developed, according to which themes are identified, classified, grouped into empirical categories (categorization process), and discussed according to the objectives of the research, the theoretical framework and the relevant literature ${ }^{(16)}$.

The thematic analysis of the narratives, developed by two researchers, resulted in the production of two categories, which address respectively: experiences in the application and receipt of Reiki; and the meanings of Reiki therapy, produced by users and therapists in SUS. The categorization added themes previously identified, due to their relationship with the object of study, and others derived from the analysis of the empirical material.

\section{RESULTS}

23 collaborators were interviewed, being: 12 users of Reiki therapy in SUS services ( 4 from the hospital institution and 8 from the NPC); and 11 therapists (4 from the NPC and 7 from the hospital).

Therapists have an average age of 60 years, ranging from 47 to 65 years. Eight of them (73\%) are female; and three (27\%), male. Regarding the level of education, one therapist (9\%) has completed elementary school; four (37\%), have completed high school; three (27\%), higher-level education; and three (27\%) of them have postgraduate studies.

The interviewed users have an average age of 47 years, ranging from 34 to 65 years, half of them female and the other half male. Regarding the level of education, two (17\%) have completed elementary school; six (50\%), have completed high school, and four (33\%) have a higher-level education.

Below, we present two thematic categories of analysis.

\section{Category 1: Experiences with Reiki therapy}

In this category, the motivations for users and therapists to use Reiki in SUS services are presented. Also reported are the benefits perceived by both after applications. 
The motivation for the use of Reiki therapy was, for most users interviewed, the need to overcome some state of specific physical and/or mental suffering. It should be noted that therapists were also able to speak from the perspective of the user of this therapy:

Reiki started to be part of my day when I was considering leaving my profession due to stress in the classroom. (User Olive tree)

A friend brought me in an oncological situation, with a bladder tumor. (Therapist Grass)

I was desperate and uncomfortable with a constipation problem [...] I also suffered from shortness of breath [...] The doctor said it was a psychological problem [...] The suffering was great, so I went in search of alternative therapies. (User Rose)

The interest in natural, non-biomedical practices, also motivated some users to look for Reiki therapy:

Ilooked for Reiki because I was always interested in natural things, like herbal medicine, reflexology, and meditation. (User Tree)

I am interested in alternative therapies and natural treatments. (User Tree)

In other situations, the prescribing of Reiki by a health professional, worked as a facilitator in access to therapy, maintaining the particularity of each user's expectations:

I went in search of Reiki based on the indication of my psychologist, with the hope of carrying out a treatment for depression without medication. (User Orchid)

A friend who had breast cancer told me about this center of natural practices, I talked to the person in charge and she suggested Lian Gong and Reiki. (User Lotus)

The motivations for the application of Reiki therapy, presented by therapists, are linked to voluntary work, in order to help other people, in return for the help they received as users of this practice in specific health-disease contexts.

My desire was to help others, so I have been working with Reiki for ten years. (Therapist Angelica)

I am a volunteer in Reiki, and I do not intend to stop. It is a way of saying thanks for the help that I had, because those who saw me before and after the treatment with Reiki noticed the changes. (Therapist Grass)

The benefits pointed out by therapists and users are mostly related to emotional balance, such as the experience of tranquility and the reduction of anxiety. The following were also identified as benefits: improved insomnia, greater well-being, and quality of life.

I have a little bit of anxiety, and it impacts my life, but with Reiki I stay calm all week. (User Tree)

Just on the first day of application, I felt the difference, because I had not been able to sleep for more than six months. Nowadays, I sleep all night and without medication. (User Daisy)
I became more loving, more harmonious, selfless, and balanced. I transcended. (Therapist Camellia)

The greatest benefits of Reiki are quality of life and well-being, as it is an energy that brings balance. (Therapist Myosotis)

\section{Category 2: Meanings of Reiki Therapy}

For each of the subjects interviewed, we must place the meanings of Reiki in the context of experiences and benefits perceived in this care practice, in addition to the influence of beliefs, personal values, and worldview on the production of meanings.

In general, the meanings of this practice, for users and therapists, converge with meanings of universal energy, life force, and divinity.

Some collaborators understand Reiki therapy as a cosmic energy that can be exchanged and that sustains, harmonizes, and balances all forms of life:

We work with the universal energy that is in everything. You don't see it, but some people feel it. This is the basis of our existence. (Therapist Grass)

Reiki is a cosmic energy. (Therapist Aroeira)

Reiki is the capture of universal energy, balance, harmony, for the maintenance of life. (Therapist Pumpkin)

I think Reiki is an exchange of energy. (User Lotus)

Reiki has been strengthening as a therapy in public health systems, but the perception of its connection with any religious or mystical belief is still contradictory:

Reiki is something that comes from above, like the King, divine, supernatural, sovereign to you. (Therapist Rosemary)

I was interested in Reiki sessions because I believe in the transmission of positive energy and I know that it has nothing to do with religion. I think it has to do with esotericism, worshiping the nature and the life of God. (User Jasmin)

It should be noted that, in this study, sometimes Reiki is perceived as a complementary therapy, sometimes as an alternative practice to the formal health care system, which assumes a noticeably biomedical character. And, in general, the expression of Reiki therapy as an integrative practice is absent.

Despite the increase in user search for this therapy and its recognition as a SUS practice, part of a public health policy, contradictions persist within health services, related to the lack of credibility by some professionals, about quality, safety, and effectiveness of this practice, as well as pertaining to the scarce offer of training courses by management, which impacts the offer of the practice:

The greatest challenges of Reiki therapy for its implantation in SUS is its recognition. People need to understand that there is a technique, it has many benefits, it calms people down, it relaxes. (Therapist Pumpkin) 
The Centers of Natural Practices are offering Reiki therapy in their units and the Secretary of Health's support and assurance are needed for therapists, so that they can act legally and safely. (Therapist Melaleuca)

The biggest challenge for expanding Reiki in SUS is in the number of professionals who apply Reiki. The demand is increasing, Reiki has been recognized and sought after by the population, but the number of Reikians does not support the great demand. It is necessary to increase human and physical resources. (Therapist Rosemary)

\section{DISCUSSION}

The methodological framework of thematic oral history, in this investigation, allowed the apprehension of narratives, with a wealth of information, for the understanding of Reiki therapy in SUS as an integrative care practice, based on the experiences and interpretations of the study participants, who witnessed the insertion of Reiki in NPICP, in 2017, and therefore were protagonists in this process. From this approach, elements emerged from the interviewees' life, professional, and health trajectories, relevant to the understanding of Reiki experiences, with a special interest in locating the motivations related to engaging in this therapy.

The study, analyzing the meanings of Reiki among therapists and SUS users, points out different interpretations related to the understanding of this therapy. Based on the narratives, the following meanings for Reiki therapy were identified: energy from above, divine, sovereign, and capable of transforming and healing; universal and cosmic energy transmission, which provides balance and well-being; energy of love and self-knowledge; and, still, a practice that we understand very little about.

Health and disease are constant phenomena in all phases of the human life cycle, like symbolically built realities within specific socio-cultural contexts. In pre-capitalist societies, for example, the concepts of health and illness were permeated by multiple explanations - magical, religious, and scientific.

Currently, the understanding of the transmission of Reiki energy as a care practice can point to the overcoming of the body versus spirit dichotomy, towards the integration of the human being. Scholars in the health field already recognize the impact of spirituality on physical health and attest to its importance in clinical practice ${ }^{(17)}$. It should be noted that spirituality is related to the transcendence of the tangible, in the relationship with the sacred, and in the intrinsic search for meanings for living and for the finite condition of life ${ }^{(18)}$.

The recognition of Reiki therapy in SUS as a complement to allopathic medicine, based on the biomedical paradigm, implies that it is not a therapeutic alternative, but rather a complementary practice to the actions and services of the formal care system, which must consider integrality of being in the interrelated bodymind-spirit dimensions and analyzing the clinical conditions of the user, for the safe application of the practice.

An integrative review on the benefits of integrative and complementary practices in nursing care showed that nurses have excelled in caring for ICHPs, mainly developing phytotherapy and massage; and that they can be applied in several clinical conditions, to promote differentiated care, with effective results, such as those seen in the areas of oncology, palliative care, obstetrics, mental health, as well as in the cases of people with chronic pain and systemic arterial hypertension ${ }^{(19)}$.

Two evidences of the advancement of the holistic paradigm in nursing science are: 1 ) the consideration of the Nursing Diagnosis "Imbalanced energy field", approved in 2016 and defined by Taxonomy II of the North American Nursing Diagnosis Association (NANDA), as the "break in the vital flow of human energy, which is usually a continuous, unique, dynamic, creative, and non-linear whole" ${ }^{\prime(20)}$; and 2) the recognition of "Nursing in Integrative and Complementary Practices" as a specialty of the professional nurse, according to Resolution No. 0581/2018 of the Federal Nursing Council (COFEN).

When analyzing the motivations for taking up Reiki therapy, it was found that the interest in natural practices, the desire to improve health conditions, and the desire to carry out voluntary work were identified among users and therapists. Also, along the narratives of the collaborators, it was observed that Reiki brought benefits to therapists and users, such as the reduction of insomnia, the better coping with problems, the decrease in the use of medications, the increase of self-esteem, and the improvement of the quality of life and well-being.

A study, which aimed to assess the effect of Reiki on the subjective well-being of people seeking this therapy, identified its ability to enhance the dimensions of positive affection and well-being, contributing to a range of satisfying and pleasurable sensations ${ }^{(21)}$.

Another study carried out with nurses, who work in the Family Health Strategy (FHS), pointed out that Reiki improved the quality of life of these professionals, balancing the physical, mental, emotional, and spiritual dimensions of the human being. And yet, it stressed the importance of using this therapy as an auxiliary strategy in the process of caring for another human being ${ }^{(22)}$.

In clinical practice, pain is among the main variables studied in the use of Reiki therapy, but there is a lack of studies dedicated to elucidating the physiological mechanisms responsible for the identified results, especially due to the wide variety of clinical conditions that trigger pain and the methodological control difficulties, homogeneity in the samples, and generalization of the results ${ }^{(23)}$.

An integrative review on the use of Reiki therapy in the relief of bio-psycho-emotional signs and symptoms induced by chemotherapy has shown that this practice can be effective and, therefore, introduced in care practice because of its results on general well-being and specific symptoms ${ }^{(24)}$.

Altogether, it is clear that the experiences with Reiki therapy integrate several dimensions of the human being, fulfilling the integrative function of this care practice.

\section{Study limitations}

As a limitation of this study, the absence of data collection in the scenario of Basic Health Units (BHU) is recognized, such as PHC services, which have stood out in expanding access to integrative and complementary practices in SUS.

\section{Contributions to the area of Nursing, Health, or Public Policy}

Considering the role of Nursing in the use of integrative and complementary practices in health care, the contribution of this study to the production of scientific knowledge in the areas of 
Collective Health and Nursing, as well as to management practices and comprehensive care in SUS' health services.

It is worth mentioning that care for people has been identified as the epistemological objective of Nursing and that, when developing integrative care practices, Nursing professionals contribute to overcoming dichotomies, such as body versus mind and normal versus pathological, enabling the exchange and production of new knowledge and experiences, which allows SUS users to mobilize their own resources in health promotion and recovery.

\section{FINAL CONSIDERATIONS}

The meaning of Reiki therapy for SUS users and therapists is plural, complex, and subjective. The production of meanings is related to beliefs, values, and experiences with this technique of laying on of hands.

The reasons for using Reiki therapy are anchored in the desire to improve quality of life, health, and well-being, based on integrative practices that perceives the human being in a multidimensional way, in addition to the biological plan — for example, by considering the energy field. The benefits identified range from specific situations, such as the relief of symptoms of a disease, to broad contexts, such as self-esteem and quality of life.

\section{FUNDING}

Coordination for the Improvement of Higher Education Personnel (CAPES).

\section{REFERENCES}

1. World Health Organization (WHO). WHO Traditional Medicine Srategy: 2014-2023 [Internet]. Geneva: WHO; 2013 [cited 2019 Oct 11 ]. Available from: http://www.who.int/medicines/publications/traditional/trm_strategy14_23/en/

2. Sousa LA, Barros NF. Integrative and Complementary Practices in the Unified Health System: progress and challenges. Rev Latino-Am Enfermagem. 2018;26:e3041. doi: 10.1590/1518-8345.2854.3041

3. Tesser CD, Sousa IMC, Nascimento MC. Traditional and complementary medicine in primary health care in Brazil. Saúde Debate. 2018;42(1):174-188. doi: 10.1590/0103-11042018s112

4. Reis BO, Esteves LR, Greco RM. Avanços e desafios para a implementação das práticas integrativas e complementares no Brasil. Rev APS. 2018;21(3):355-64. doi: 10.34019/1809-8363.2018.v21.16383

5. Ministério da Saúde (BR). Secretaria-Executiva. Secretaria de Atenção à Saúde. Glossário temático: práticas integrativas e complementares em saúde [Internet]. Brasília: Ministério da Saúde; 2018[cited 2019 Oct 11]. Available from: https://portalarquivos2.saude.gov.br/images/ pdf/2018/marco/12/glossario-tematico.pdf

6. Ferraz G, Rodrigues MRK, Lima SAM, Lima MAF, Maia GL, Pilan Neto CA, et al. Is reiki or prayer effective in relieving pain during hospitalization for cesarean? a systematic review and meta-analysis of randomized controlled trials. São Paulo Med J. 2017;135(2):123-132. doi: 10.1590/1516-3180.2016.0267031116

7. Demir DM. The effect of reiki on pain: a meta-analysis. Complement Ther Clin Pract. 2018;31(2):384-387. doi: 10.1016/j.ctcp.2018.02.020

8. Jahantiqh F, Abdollahimohammad A, Firouzkouhi M, Ebrahiminejad V. Effects of Reiki versus physiotherapy on relieving lower back pain and improving activities daily living of patients with intervertebral disc hernia. J Evid Based Integr Med. 2018. doi: 10.1177/2515690X18762745

9. Baldwin AL, Vitale A, Brownell E, Kryak E, Rand W. Effects of Reiki on pain, anxiety, and blood pressure in patients undergoing knee replacement: a pilot Study. Holist Nurs Pract. 2017;31(2):80-89. doi: 10.1097/HNP.0000000000000195

10. Kurebayashi L et al. Massage and Reiki used to reduce stress and anxiety: randomized clinical trial. Rev LatinAm Enferm. 2016. 24:e2834 doi:10.1590/1518-8345.1614.2834

11. lacorossi L, Di Ridolfi P, Bigiarini L, Giannarelli D, Sanguineti G. The impact of Reiki on side effects in patients with head-neck neoplasia undergoing radiotherapy: a pilot study. Prof Inferm. 2017;70(3):214-221. doi: 10.7429/pi.2017.704214

12. Bremner MN, Blake BJ, Wagner VD, Pearcey SM. Effects of Reiki with music compared to music only among people living with HIV. J Assoc Nurses AIDS Care. 2016;27(5):635-47. doi: 10.1016/j.jana.2016.04.004

13. Charleswortha E, Hughesb J, Planta H, Carballoa L. Complementary therapy for people with cancer: the patient's perspective. Europ J Integrat Med. 2018;17:26-32. doi: 10.1016/j.eujim.2017.10.009

14. Palmeira ABP, Gewehr RB. O lugar da experiência do adoecimento no entendimento da doença: discurso médico e subjetividade. Ciênc Saúde Coletiva. 2018;23(8):2469-78. Available from: 10.1590/1413-81232018238.15842016

15. Meihy JCSB. Manual de história oral. São Paulo: Loyola;2005.

16. Bardin L. Análise de conteúdo. Lisboa: Edições 70; 2009.

17. Guimaraes HP, Avezum A. O impacto da espiritualidade na saúde física. Rev Psiquiatr Clín. 2007;34(1):88-94. doi: 10.1590/ S0101-60832007000700012

18. Costa MS, Dantas RT, Alves CGS, Ferreira ER, Silva AF. Espiritualidade e religiosidade: saberes de estudantes de medicina. Rev Bioét. 2019;27(2):350-358. doi: 10.1590/1983-80422019272319 
19. Mendes DS, Moraes FS, Lima GO, Riegel F. Benefícios das práticas integrativas e complementares no cuidado de enfermagem J. Health NPEPS. 2019;4(1):302-318. doi: 10.30681/252610103452

20. Nanda, Diagnósticos de enfermagem da NANDA-I: definições e classificação 2018-2020. Brasil: Artmed; 2018.

21. Bessa JHN. Efeito do Reiki no bem-estar subjetivo: estudo experimental. Enferm Glob. 2017;16(48):1695-6141. doi:/10.6018/ eglobal.16.4.259141

22. Freitag VL, Andrade A, Badke MR, Heck RM, Milbrath VM. A terapia do reiki na Estratégia de Saúde da Família: percepção dos enfermeiros. Rev Pesqui: Cuid Fundam. 2018;10(1):248-53. doi: 10.9789/2175-5361.2018.v10i1.248-253

23. Raso J. Alternative Healthcare: a comprehensive guide. Amhest, NY: Prometheus Books; 2015.

24. Beulke LS, Vannucci L, Salles LF, Turrini RNT. Reiki in the relief of chemotherapy-related biopsychoemotional signs and symptoms. Cogitare Enferm. 2019;24(e56694) doi: 10.5380/ce.v24i0.56694 